Research, part of a Special Feature on Effects of Roads and Traffic on Wildlife Populations and Landscape Function

\title{
Integration of Regional Mitigation Assessment and Conservation Planning
}

\author{
$\underline{\text { James H. Thorne }}^{1}, \underline{\text { Patrick R. Huber }}^{1}, \underline{\text { Evan H. Girvetz }}^{2}, \underline{\text { Jim Quinn }}^{1}{ }^{\text {, and Michael C.McCoy }}{ }^{1}$
}

\begin{abstract}
Government agencies that develop infrastructure such as roads, waterworks, and energy delivery often impact natural ecosystems, but they also have unique opportunities to contribute to the conservation of regional natural resources through compensatory mitigation. Infrastructure development requires a planning, funding, and implementation cycle that can frequently take a decade or longer, but biological mitigation is often planned and implemented late in this process, in a project-by-project piecemeal manner. By adopting early regional mitigation needs assessment and planning for habitat-level impacts from multiple infrastructure projects, agencies could secure time needed to proactively integrate these obligations into regional conservation objectives. Such practice can be financially and ecologically beneficial due to economies of scale, and because earlier mitigation implementation means potentially developable critical parcels may still be available for conservation. Here, we compare the integration of regional conservation designs, termed greenprints, with early multi-project mitigation assessment for two areas in California, USA. The expected spatial extent of habitat impacts and associated mitigation requirements from multiple projects were identified for each area. We used the reserve-selection algorithm MARXAN to identify a regional greenprint for each site and to seek mitigation solutions through parcel acquisition that would contribute to the greenprint, as well as meet agency obligations. The two areas differed in the amount of input data available, the types of conservation objectives identified, and local land-management capacity. They are representative of the range of conditions that conservation practitioners may encounter, so contrasting the two illustrates how regional advanced mitigation can be generalized for use in a wide variety of settings. Environmental organizations can benefit from this approach because it provides a platform for collaboration with infrastructure agencies. Alone, infrastructure agency mitigation obligations will not satisfy all greenprint objectives, but they can be a major contributor to the ongoing process of implementing ecologically sustainable regional plans.
\end{abstract}

Key Words: California; conservation planning; greenprint; MARXAN; regional mitigation assessment; transportation planning

\section{INTRODUCTION}

Government agencies that develop infrastructure such as roads, canals, and power lines are frequently required to mitigate the ecological impacts of their projects. Road networks in particular have been extensively studied and shown to have multiple direct, indirect, and cumulative ecological impacts (Forman and Alexander 1998, Trombulak and Frissell 2000, Forman et al. 2003, National Academy of Sciences 2005) and to affect sizeable areas, including one-fifth of the United States
(Forman 2000). The U.S. federal government has recognized the importance of addressing road impacts systematically through the passing of the "Safe, Accountable, Flexible, Efficient Transportation Equity Act" (SAFETEA-LU; U.S. Congress 2005), that directs transportation planners to adopt early impact assessment and incorporate regional planning approaches. The SAFETEA-LU's main concepts are: (1) that some habitat-level impacts can be identified before construction, either through field surveys or geographic information systems (GIS) analyses; (2) that the combined obligations 
from multiple projects in a region can potentially allow more biologically effective site selection of lands for compensatory mitigation; and (3) that selection of mitigation lands from a subset of the region that has been identified as a regional conservation greenprint permits selection of more ecologically effective mitigation lands and permits mitigation solutions to contribute to a broader conservation effort.

Multiple U.S. federal agencies issued a report that recommends that early environmental impact assessment and planning should help guide the development of infrastructure projects (Brown 2006). Some state transportation agencies are addressing this call, as evidenced by projects in Washington on Interstate Highway I-90 (http://ww w.wsdot.wa.gov/Projects/I90/SnoqualmiePassEast/ HyaktoKeechelusDam/ ) and Florida's "Efficient Transportation Decision Making" initiative based on conservation assessments for Florida (http://etd mpub.fla-etat.org/est/; Hoctor et al. 2000, Florida Department of Transportation 2001), among others (Brown 2006). These plans frequently address the fragmentation impacts of road networks on populations of species of concern by analyzing the need for habitat connectivity, identifying habitat locations critical for maintaining or restoring such connectivity, and improving road-crossing structures.

However, most transportation-project compensatory mitigation is still conducted late in the planning process and in a piecemeal, project-by-project manner. This approach has several drawbacks. First, it can result in less ecologically effective mitigation because small off-site parcel sizes acquired to meet impact obligations are not planned in relation to regional conservation goals. Second, it can be more expensive because mitigation undertaken late in the project cycle may cost more. Third, the mitigation may take longer to develop because permitting practices involve repetitious procedures that can unpredictably delay project delivery (Hardy 2007). Traditional practice does not pool mitigation resources from multiple projects that would allow for the purchase of larger, more economical land parcels. Environmental review also typically does not occur until a project has already received funding authority, at which point, for the purposes of the National Environmental Policy Act, it becomes a "programmed project" subject to environmental review. To have reached this stage, however, projects have usually already made significant site investments in engineering design, which reduces the flexibility to avoid or minimize project environmental impacts.

This late environmental assessment of road-project impacts is the primary cause of costly construction delays (American Association of State and Highway Transportation Officials 2003). For example, in California, state transportation-project cost overruns due to environmental review delays are estimated at $\$ 59$ million per year (Byrne 2005). Therefore, development of regional impacts assessment and mitigation plans may prove beneficial to government because they can help reduce environmental review time and permit the early acquisition of lands that could be used as mitigation banks, thus providing mitigation credits for multiple projects from locations of superior ecological value than those that might be available at the end of individual project cycles.

The potential for a GIS approach to assess landscape-scale road impacts has long been recognized (Treweek and Vietch 1996, Miller 1999). Quantitative GIS-based estimates of impact range from measures of landscape fragmentation (Jaeger 2000, Girvetz et al. 2008a) to providing map-based context for direct measures of trafficcaused mortality (e.g., Clevenger et al. 2003, Orlowski 2008, Smith-Patten and Patten 2008). Geographic information systems can also be used to identify the footprint, or area extent, of planned road projects. These footprints can be overlaid on habitat-type maps to measure expected future habitat impacts for road projects in a region, leading to a summary analysis of aggregate regional impacts (Thorne et al. 2006b, Thorne et al. 2009). This GISbased assessment can contribute to proactive environmental management (O'Neill et al. 1997, Dale et al.2005) by informing systematic mitigation planning.

The California Department of Transportation (Caltrans) has initiated efforts to develop early mitigation needs assessment capacity. As part of this capacity-development effort, two areas of California were selected-differing in data availability, conservation objectives, and local landmanagement capacity - as case studies of the application of GIS-based mitigation needs assessment and greenprint integration. The approach used is a modification of systematic conservation planning (Margules and Pressey 2000) that consists of first identifying regional conservation objectives through a combination of 
gap analysis (Scott et al. 1993, Davis et al. 1998) and landscape-connectivity analysis (Beier and Noss 1998, Beier et al. 2008). Subsequently, we identified a set of privately owned parcels that could be used meet the regional greenprint goals through the use of MARXAN (Ball and Possingham 2000). Finally, projected land-acquisition needs to offset habitat impacts from multiple road projects were used in a second MARXAN analysis to identify parcels that could fulfill those obligations and also contribute to the regional greenprint (Fig. 1).

We conducted this analysis for two regions in California with different levels of information available and differing local capacity for management of conservation lands. Here, we use those differences to illustrate how they affected the assessment of regional advance-mitigation planning. The steps outlined in the Methods were applied to both regions, as data availability allowed.

\section{METHODS}

The following steps were taken to develop regional greenprints and incorporate projected agency mitigation needs (Fig. 1).

Background Information

1. Identify each study area boundary

2. Identify and obtain available biological, spatial, economic, infrastructure, and other data for each study area from government agencies, stakeholders, and other sources

\section{Regional Conservation Assessment}

1. Determine regional conservation target levels for the protection of different habitat types by consulting the stakeholders and analyzing the data collected

2. Analyze the region from the perspective of landscape connectivity

3. Run a parcel-level reserve-selection algorithm to identify candidate parcels for a conservation plan to meet the biodiversity conservation target and habitat connectivity objectives
Road Impacts

1. Identify the spatial extent (footprint) of each road-construction project, and assess its habitat-level impacts

2. Determine the additive spatial extent of habitat impacts from all road projects

3. Determine the mitigation ratios typically required for impacts to each habitat type, and identify the likely required extent of lands for all road projects per region

Integration of Mitigation Needs and Regional Greenprint

1. Run a second reserve-selection analysis to determine how transportation-project mitigation needs could fit into the conservation plan

\section{Background Information}

\section{Study areas}

The two study areas are located in California (Fig. 2).

Study area 1, the Elkhorn Slough watershed (ES) occupies 20648 ha on California's central coast (Fig. 2). The study area boundary was delineated as the watershed boundary defined by the HUC8 watershed boundaries of the Calwater 2.2.1 multiscale watershed map (California Interagency Watershed Mapping Committee (CIWMC) 2004). Important land-cover types include lagoon, freshwater, and saltwater coastal wetlands, coast chaparral, coast live oak woodlands, mixed oakconifer woodlands, and agriculture. The watershed is the location of a number of important transit routes between northern and southern California, including Highways 101 and 1, and contains 8934 land-ownership parcels.

The ES watershed has more data and landmanagement capacity than the second study area. The Elkhorn Slough Foundation (ESF), active in the watershed for over 10 years (ESF and Scharffenberger 1999, ESF and The Nature 
Fig. 1. Steps taken to develop a regional greenprint of conservation needs (left-side process) and integrate a transportation agency's compensatory mitigation obligations into the greenprint (right-side process).

\section{Regional greenprint development}

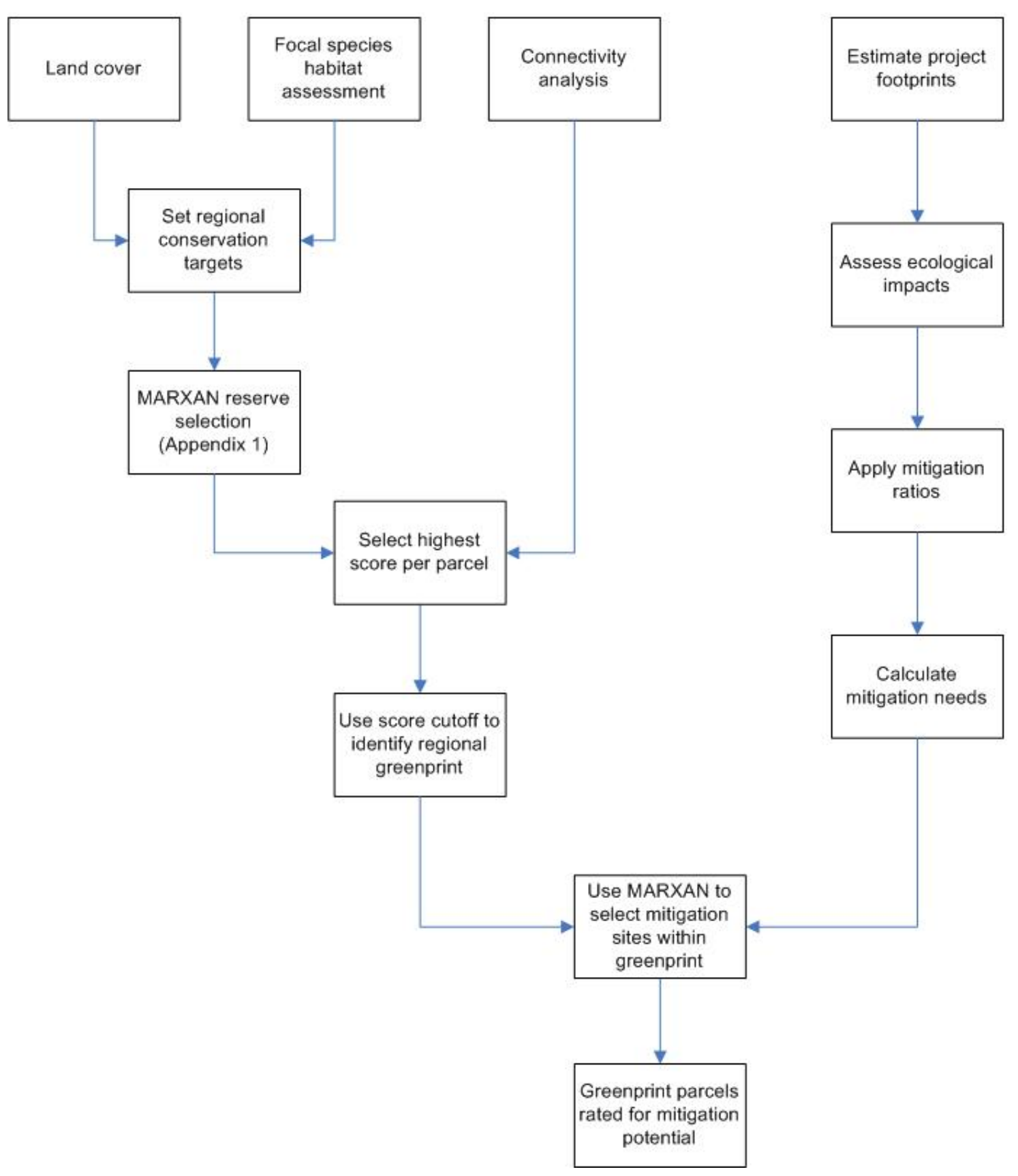

\section{Regional mitigation assessment}


Fig. 2. Location of the Elkhorn Sough and Pleasant Grove study areas. Study-area insets show the landcover maps used for each study. The Elkhorn Slough study-area map was derived from high-resolution aerial photography, the Pleasant Grove map selected from a state-wide, satellite-image-based map.

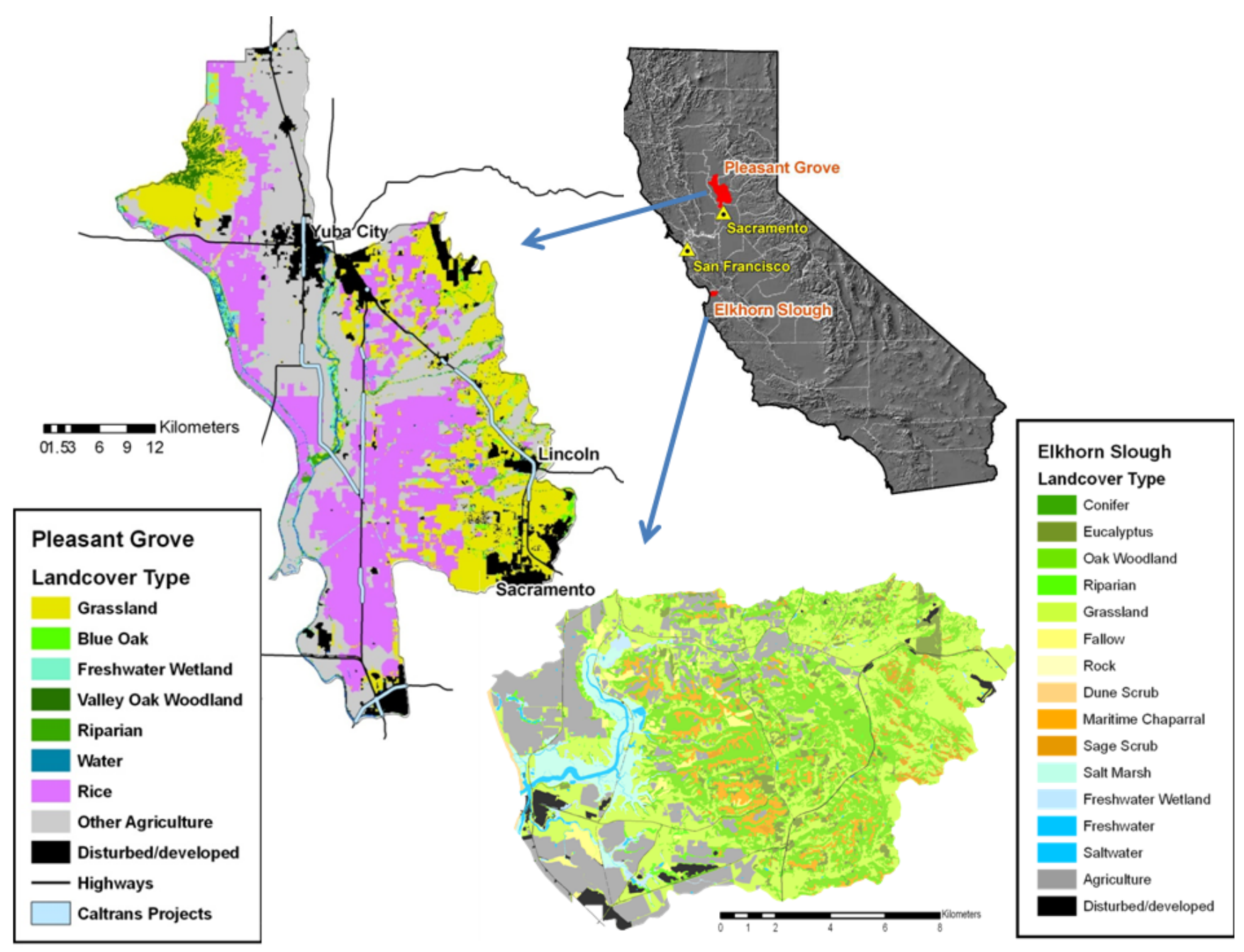

Conservancy (TNC) 2002), conserves and manages land, and is well regarded by government agencies. This group provided a high-resolution land-cover map (more spatial detail than the one used in the second study) that we used as an important base layer. The ESF also provided a ranking of the proportion of each habitat type in the watershed to be used as conservation targets while running the MARXAN model to identify the regional greenprint.

Study area 2, "Pleasant Grove" (PG) comprises four watersheds and portions of five counties
(Sacramento, Placer, Sutter, Yuba, and Butte), totaling 516000 ha (Fig. 2). It contains 54550 parcels used in this analysis; dense urban-area parcels were masked out for computer-efficiency purposes. The four-watershed region (Sutter Bypass, Olivehurst, Lower Bear River, and Pleasant Grove) was defined by the same HUC8 watershed map (CIWMC 2004) as the ES study. This study area is largely agricultural, although there has been accelerated urbanization over the past decade or so. Remaining natural habitat fragments are largely composed of annual grasslands, freshwater emergent wetlands, riparian forest, and valley 
(Quercus lobata) and blue oak (Q. douglasii) woodlands.

The PG study-area extent allowed for identification of habitat connectivity potential between more ecologically intact areas in the Sierra Nevada foothills on the east and the Sutter Buttes and Sacramento River to the west. Connectivity occurs at many spatial scales; in this case, both within and across the study area. The larger area (compared with ES) permitted incorporation of wildlife corridors into the regional greenprint. The PG region has no active non-governmental organization or other group that had produced comprehensive conservation objectives.

\section{Base data}

Available GIS data for each region (Table 1) were combined into a geodatabase. Map layers included: county boundaries, finest-scale-available land cover, current development, parcel boundary map, roads, existing conservation lands map, location of planned and/or programmed highway projects, and known locations of threatened and endangered species.

\section{Parcel data}

Land-ownership parcel boundaries were assembled from data provided by county governments. These data were in raw form; we completed the maps by selecting the centerline of each road and merging the area from property edge to road centerline, so that study areas contained seamless polygons representing ownership parcels.

The two ES counties (Monterey and San Benito) provided parcel boundaries and land value. San Benito County also provided year of last sale, with some sales dating back to 1978 (Monterey County did not provide year of last sale). These data sets were spatially joined, and the assessed value was calculated for the entire ES study area by using the natural log of parcel area plotted against the natural $\log$ of the parcel cost from 8934 parcels (Girvetz et al. 2008b).

In California, assessed land value is only registered when a parcel is sold. The loglog plot showed a spread of parcel costs within parcel-size classes, due to the date of each parcel assessment, because land values have consistently increased over time. To account for this bias in the data due to parcels being assessed at different times, this project estimated the parcel cost today by identifying the $90 \%$ quantile regression line through the data points, which represents the price/area for the most recent $10 \%$ of sales.

The parcel value:parcel area ratio derived for the ES study was applied to the PG parcel sizes, as no parcel-value data were available for that region. Parcel value was later used as a required input for the reserve-selection algorithm MARXAN.

\section{Regional Conservation Assessment}

There are many potential combinations of planning units (ownership parcels in this study) that will achieve the habitat protection targets set during conservation planning. However, most of these combinations will be less than optimal in terms of the cost associated with their inclusion in a reserve network (Cameron et al. 2008). MARXAN is software that uses an optimization algorithm to identify area-based solutions for conservation planning (Ball and Possingham 2000). This algorithm seeks to meet ecological representation targets set by the user while minimizing the cost of the suite of selected parcels (measured either through true acquisition cost or by a proxy such as area of the parcel) as well as reducing the cost (both economic and ecological) associated with a reserve network's boundary length. Parcels analyzed can be weighted by their size, boundary area, habitat types, and other ecological values such as their occurrence within areas identified as wildlife corridors (Appendix 1). The MARXAN output includes one "best" solution set of parcels (that which achieves the conservation goals for the lowest cost) as well as a score for each parcel representing the number of runs in which that parcel appeared in a potential solution. We used MARXAN for two purposes: first, to identify a portfolio of parcels that meet regional greenprint conservation goals; and second to identify a smaller portfolio of suitable compensatory mitigation parcels.

\section{Elkhorn Slough}

The ESF identified habitat-type conservation targets (Table 2). These targets were inputted into MARXAN, which was run 1000 times using a combination of the parcels attributed with the estimated current-day parcel cost, and the area of each major habitat type per parcel. Simulated 
Table 1. Data differences between Elkhorn Slough and Pleasant Grove study areas.

\begin{tabular}{|c|c|c|}
\hline & Elkhorn Slough & Pleasant Grove \\
\hline Land-cover map & $\begin{array}{l}\text { High-resolution vector map ( }<1 \text { ha) derived from } \\
\text { aerial photography and developed for the study } \\
\text { by the Elkhorn Slough Foundation (ESF and } \\
\text { Scharffenberger 2002) }\end{array}$ & $\begin{array}{l}\text { Raster } 100 \mathrm{~m} \text { land-cover map obtained from a } \\
\text { state-wide GIS of land cover, derived from satellite } \\
\text { TM imagery (California Department of Forestry } \\
\text { and Fire Protection 2002) }\end{array}$ \\
\hline $\begin{array}{l}\text { Land-ownership } \\
\text { parcels }\end{array}$ & $\begin{array}{l}\text { Monterey County and San Benito County parcel } \\
\text { data sets, obtained from county }\end{array}$ & $\begin{array}{l}\text { Sacramento County, Placer County, Sutter County, } \\
\text { Yuba County, and Butte County parcel data sets, } \\
\text { obtained from county }\end{array}$ \\
\hline $\begin{array}{l}\text { Existing } \\
\text { conservation lands }\end{array}$ & $\begin{array}{l}\text { Elkhorn Slough Foundation and State-wide } \\
\text { Public and Conservation Trust Lands data set } \\
\text { (California Resources Agency 2007) }\end{array}$ & $\begin{array}{l}\text { State-wide Public and Conservation Trust Lands } \\
\text { data set (California Resources Agency 2007) }\end{array}$ \\
\hline $\begin{array}{l}\text { Caltrans road- } \\
\text { construction } \\
\text { projects }\end{array}$ & State-wide Caltrans data set & State-wide Caltrans data set \\
\hline $\begin{array}{l}\text { Conservation } \\
\text { objectives }\end{array}$ & $\begin{array}{l}\text { Provided by Elkhorn Slough Foundation (ESF } \\
\text { and Scharffenberger 2002) }\end{array}$ & $\begin{array}{l}\text { Developed for the project using principles from the } \\
\text { scientific literature (Beier and Noss 1998, } \\
\text { Margules and Pressey 2000, Svancara et al. 2005) }\end{array}$ \\
\hline $\begin{array}{l}\text { T \& E species } \\
\text { known locations }\end{array}$ & $\begin{array}{l}\text { California Department of Fish and Game } \\
\text { (CDFG) database (CDFG 2007) }\end{array}$ & CDFG database (CDFG 2007) \\
\hline Wildlife corridors & not available & Huber et al. 2008 \\
\hline $\begin{array}{l}\text { Modeled species } \\
\text { distributions }\end{array}$ & Did not use & Hollander (unpublished data) \\
\hline Roads & Did not use & $\begin{array}{l}\text { Used for least-cost corridor analysis (California } \\
\text { Spatial Information Library 2000) }\end{array}$ \\
\hline
\end{tabular}

annealing was used as the optimization algorithm, and a boundary modifier of 2000 was selected as an optimum for the trade-off between the selection of the financially cheapest parcels and the selection of adjacent parcels that minimize the length of the overall reserve boundary. All other MARXAN parameters were default.

\section{Pleasant Grove}

The PG area has no conservation organization exclusively dedicated to it, and hence no local conservation targets have been regionally identified. Therefore, we selected natural-habitat representation goals of $50 \%$ for each habitat type (Table 2), with the exception of grasslands. Because a much larger proportion of grasslands than other vegetation types remain in the study area, we used a $25 \%$ grassland conservation goal in order to focus the resulting conservation network on a more historic ratio of vegetation types. These conservation targets were for 1000 MARXAN runs. We used the boundary modifier and parcel-value estimates based on the ES study.

Because the PG study area is composed mostly of degraded landscapes, a second MARXAN analysis was conducted to target habitat types used by species that can use agricultural landscapes. We modeled potential habitat for 10 focal species (Table 3; Huber et al. 2008) that are either already listed as threatened or endangered, or appear to be declining 
Table 2. Extent of dominant habitat types in each study area and the conservation objectives. For Elkhorn Slough, conservation objectives were defined by the Elkhorn Slough Foundation. Identified habitat extents were then used in the MARXAN run to identify the regional conservation design. For Pleasant Grove, we defined the habitat conservation targets. The target conservation amount for annual grasslands equals the middle of the three percentages shown. In the Pleasant Grove study, these conservation target levels were used in one of two MARXAN runs that defined the suitability of ownership parcels for the regional conservation design. The highest parcel value derived either from the MARXAN runs or the connectivity modeling was then used in the regional conservation design. This design was then used as a boundary within which the mitigation needs exercise ranked the suitability of parcels.

\begin{tabular}{|c|c|c|c|c|}
\hline Habitat Type & Total Hectares & $\%$ Protected & Target $\%$ & Total Conservation Target \\
\hline \multicolumn{5}{|l|}{ Elkhorn Slough } \\
\hline Dune Scrub & 53.4 & 82 & 95 & 50.6 \\
\hline Mudflat & 485.2 & 86 & 95 & 460.9 \\
\hline Saltmarsh & 459.7 & 72 & 95 & 437.1 \\
\hline Saltwater & 241.2 & 71 & 90 & 217.3 \\
\hline Freshwater & 78.5 & 19 & 75 & 58.7 \\
\hline Freshwater Wetlands & 245.6 & 30 & 75 & 184.1 \\
\hline Maritime Chaparral & 950.6 & 24 & 75 & 713.1 \\
\hline Riparian & 337.9 & 14 & 65 & 219.7 \\
\hline Conifer & 40.5 & 6 & 25 & 10.1 \\
\hline Eucalyptus & 803.3 & 7 & 30 & 240.8 \\
\hline Grassland & 7006.3 & 8 & 45 & 3152.9 \\
\hline Coast Live Oak Woodland & 4909.6 & 10 & 50 & 2454.8 \\
\hline Sage Scrub & 363.8 & 13 & 50 & 181.7 \\
\hline Rock & 1.2 & 0 & 10 & 0.0 \\
\hline Disturbed & 4671.3 & 8 & 0 & 0.0 \\
\hline \multicolumn{5}{|l|}{ Pleasant Grove } \\
\hline Annual Grassland & 43020 & 9.4 & 25 & 10755.0 \\
\hline Blue Oak-Foothill Pine & 495 & 20.2 & 50 & 247.5 \\
\hline Blue Oak Woodland & 1463 & 9.4 & 50 & 731.5 \\
\hline Freshwater Emergent Wetland & 4586 & 23.7 & 50 & 2293.0 \\
\hline Montane Hardwood-Conifer & 3 & 0 & 50 & 1.5 \\
\hline
\end{tabular}




\begin{tabular}{lcccc}
\hline Montane Hardwood & 806 & 4.7 & 50 & 403.0 \\
Valley Oak Woodland & 2170 & 0 & 50 & 1085.0 \\
Valley Foothill Riparian & 2400 & 23.6 & 50 & 1200.0 \\
Unknown Conifer Type & 53 & 3.8 & 50 & 26.5 \\
Unknown Shrub Type & 198 & 9.1 & 50 & 99.0 \\
Vernal Pool Complex & 21629 & 8.1 & 50 & 10814.5 \\
\hline
\end{tabular}

as a result of ecological threats in the region (Lambeck 1997).

Potential habitat area for each focal species was calculated per parcel. We then selected $30 \%$ representation for each species as conservation targets in this analysis. This permitted the identification of conservation-target lands that potentially could be restored to greater ecological functionality, or that had remnant fragments of habitat on them suitable for use by some species (Huber 2008).

We identified potential wildlife corridors for four species-giant garter snake (Thamnophis gigas), American badger (Taxidea taxus), tule elk (Cervus elaphus nannodes), and bobcat (Lynx rufus)-for incorporation into the regional conservation design. This was not done at ES because of the smaller spatial extent and the lack of information beyond the borders of the study area from which to infer potential landscape connectivity. Each parcel was assigned a connectivity value equal to the average value for the four species.

These analyses produced land-cover, focal-species, and wildlife-corridor values for each parcel. To calculate the conservation value for each parcel, we combined the land-cover and focal-species MARXAN output values to a normalized conservation value scale of $0-1000$. We also scored the connectivity values per parcel from 0-1000, with the highest corridor value equal to 1000 . Finally, we selected the higher value from the two and assigned it as the overall greenprint value of each parcel to the region.

The regional PG greenprint was then identified by selecting parcels in descending order of conservation value until the sum area of the parcels reached $25 \%$ of the full study area. These selected parcels served as the "mask" within which parcels were evaluated for utility in meeting Caltrans mitigation needs in the subsequent analysis.

\section{Road Impacts}

The location of each funded road-construction project was obtained from Caltrans. We queried Caltrans' biologists to develop a classification of road-construction project types (Thorne et al. 2009). These were used to identify a buffer to apply to each project in order to define the area impacted by each project (Appendix 2). For example, road widening extends $30.5 \mathrm{~m}$, whereas a passing lane has a $10-\mathrm{m}$ extent.

The footprint from each project was overlaid on the habitat map. As the habitat maps had a 100-m cell size, we buffered each project by $250 \mathrm{~m}$ from road centerline (for a 500-m width) and identified the proportion of each habitat type within the general area of the project. Then, we multiplied the actual calculated area of the footprint by the percentage identified for each habitat type to obtain an area estimate of the total impacts of each project. This permitted a more complete representation of all vegetation types found along the projects than could be obtained if the project footprint were used to sample the vegetation map directly because some types present in the region would likely not have part of one of their raster cells fall in the area, even if there were some small amount of that vegetation type in the impact zone.

Impacted area estimates were summed by habitat type across all the projects in each region. Consultation with Caltrans' biologists provided us with mitigation ratios commonly applied for each 
Table 3. Ten species used in the Pleasant Grove study to identify preferred habitat locations that include agricultural land. These species were selected because they were legally protected, could be used to assess landscape connectivity, or could use agricultural settings that could be restored to more suitable habitat.

\begin{tabular}{|c|c|c|c|}
\hline Focal Species & Reason for Selecting & Federal Status & California State Status \\
\hline Tule elk (Cervus elaphus nannodes) & $\begin{array}{l}\text { Regional connectivity, } \\
\text { landscape restoration }\end{array}$ & & \\
\hline Bobcat (Lynx rufus) & Forest connectivity & & \\
\hline American badger (Taxidea taxus) & $\begin{array}{l}\text { Grassland area and } \\
\text { connectivity }\end{array}$ & & Species of special concern \\
\hline $\begin{array}{l}\text { Giant garter snake (Thamnophis } \\
\text { gigas) }\end{array}$ & $\begin{array}{l}\text { Wetland area and } \\
\text { connectivity, regulatory }\end{array}$ & Threatened & Threatened \\
\hline Swainson's hawk (Buteo swainsoni) & $\begin{array}{l}\text { Agricultural interface, } \\
\text { regulatory }\end{array}$ & & Threatened \\
\hline $\begin{array}{l}\text { Yellow-billed cuckoo (Coccyzus } \\
\text { americanus) }\end{array}$ & Riparian forest area & & Endangered \\
\hline Sandhill crane (Grus canadensis) & $\begin{array}{l}\text { Waterfowl indicator, wildlife- } \\
\text { friendly agriculture }\end{array}$ & & Threatened \\
\hline $\begin{array}{l}\text { Tricolored blackbird (Agelaius } \\
\text { tricolor) }\end{array}$ & $\begin{array}{l}\text { Wetland area, wildlife- } \\
\text { friendly agriculture }\end{array}$ & & Species of special concern \\
\hline $\begin{array}{l}\text { VELB (Desmocerus californicus } \\
\text { dimorphus) }\end{array}$ & Important regulatory species & Threatened & \\
\hline Vernal pool species & Vernal pool area, regulatory & Multiple endangered & Multiple endangered \\
\hline
\end{tabular}

habitat type in each area (Table 4). We multiplied projected habitat impacts by the anticipated mitigation ratios to identify the agency's mitigation needs in each study area.

\section{Integration of Mitigation Needs and Regional Greenprint}

The habitat mitigation needs for both projects (Table 4) were used as the objectives for a second round of MARXAN model runs. In each case, the regional greenprint was used as a boundary within which parcels were permitted to be selected. The model was run 1000 times with other input parameters identical to the previous MARXAN analyses. A map was generated showing the number of times each parcel was selected.

\section{RESULTS}

\section{Background Information}

Regional context varied between the projects: the quality and scale of data available for analyses differed, as did capacity of local non-profit groups to implement and manage conservation lands and the components used for the regional conservation design.

Using a quantile regression of the top $10 \%$ values, we found parcel price per hectare had a strong 
Table 4. Mitigation ratios for the Elkhorn Slough and Pleasant Grove study areas.

\begin{tabular}{llll}
\hline \hline Habitat Type & Footprint (ha) & Ratio & Mitigation Target (ha) \\
\hline Elkhorn Slough & & & \\
Oak Woodland & 59.5 & $3: 1$ & 178.4 \\
Freshwater Wetland & 4.4 & $3: 1$ & 13.1 \\
Maritime Chaparral & 1.3 & $3: 1$ & 4 \\
Pleasant Grove & & & \\
Annual Grasslands & 103.5 & $1: 1$ & 103.5 \\
Blue Oaks & 3.6 & $4: 1$ & 14.4 \\
Wetlands & 2.4 & $2.5: 1$ & 6.1 \\
Valley Oak & 0.0 & $4: 1$ & 0.0 \\
Riparian Forest & 2.8 & $5: 1$ & 14.2 \\
Rice & 74.3 & $1: 1$ & 74.3 \\
Vernal Pools & 120.0 & $6: 1$ & 720.3 \\
\hline
\end{tabular}

negative correlation $(p<0.0001)$ with increasing parcel size (Fig. 3):

$\ln ($ cost $/$ acre $)=12.55017-0.79771(\ln ($ acres $))$

We assumed this relationship to estimate cost for parcels in the MARXAN analysis for both study areas. The width of the distribution of points represents the years of parcel value on record. The lower edge of the cloud represents parcels that are undervalued by the county assessor's records because they had not been updated (by a change in ownership) for many years.

\section{Road Impacts}

\section{Elkhorn Slough}

There were four road projects in the ES study area, which impacted three major habitat types: maritime chaparral, coast oak woodlands, and freshwater riparian wetlands. Each of these types requires a 3:1 ratio for mitigation, leading to a GIS-based measure of mitigation needs of 1.6 ha maritime chaparral, 72.2 ha coast live oak woodlands, and 5.3 ha freshwater wetlands.

\section{Pleasant Grove}

There were 18 road projects analyzed for the PG area (Fig. 2), leading to 923 ha of mitigation needs spread across seven habitat types (Table 3). Included in the mitigation needs for the PG area are vernal pools and rice fields (habitat for T. gigas).

\section{Regional Conservation Assessment and Mitigation Needs Assessment}

\section{Elkhorn Slough}

The MARXAN runs identified a portfolio of regional conservation greenprint parcels (Fig. 4) 
Fig. 3. Graph showing the relationship between the natural log area of a given parcel (bottom axis) and the natural log price per acre (left axis). Note larger parcels tend to cost less per acre. The dashed orange line is the $90 \%$ quantile regression line, which models this relationship between parcel area and parcel cost, accounting for inflation in land values over time.

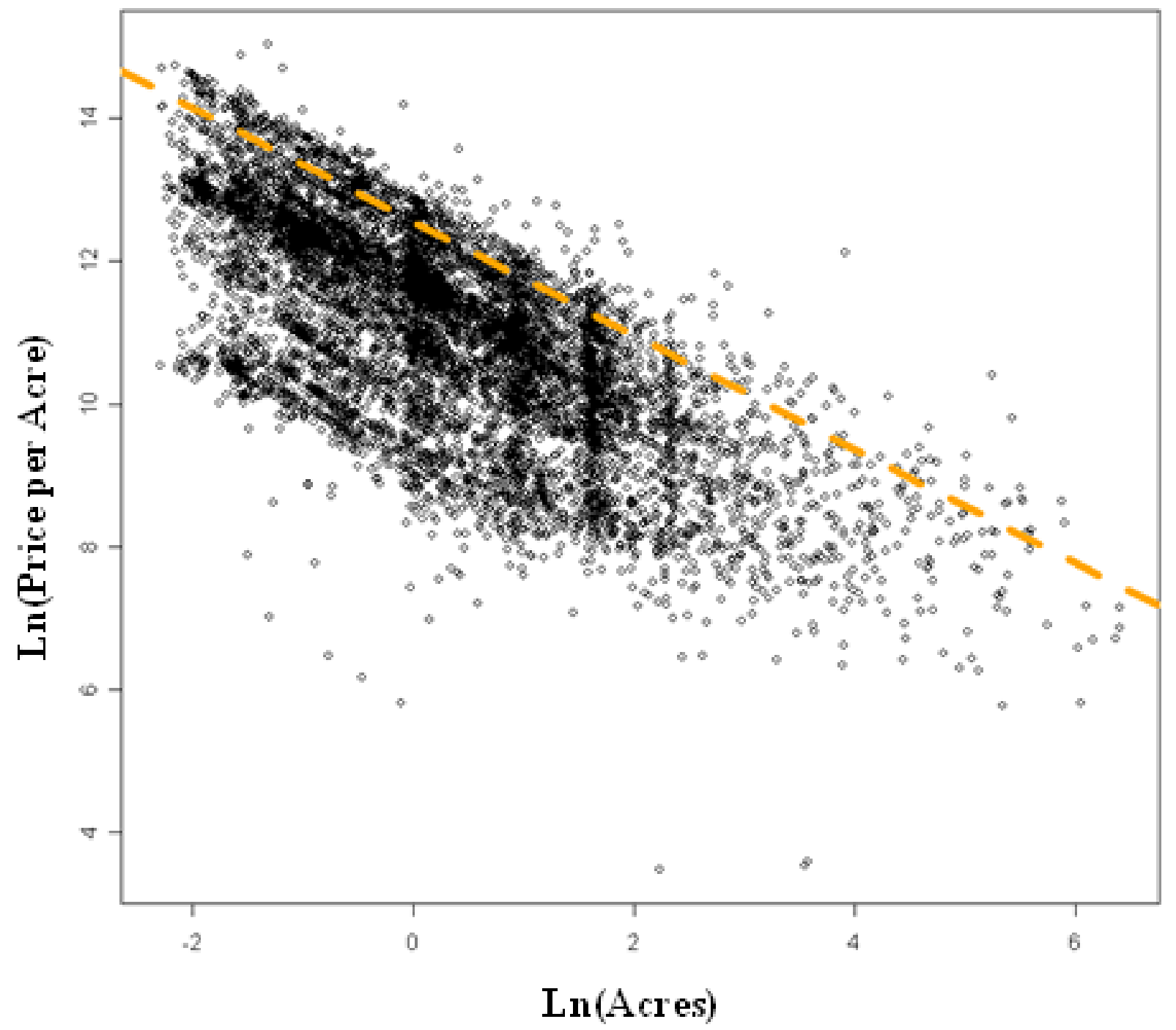


and a portfolio of parcels that could meet roadproject mitigation needs (Fig. 4, lower). The resulting green- to blue-colored parcels represent potential portfolio sites that are most irreplaceable in contributing to greenprint and mitigation goals, while minimizing parcel cost and length of reserve boundary exposed to private lands.

\section{Pleasant Grove}

Habitat-type and focal-species surfaces were combined with the connectivity analysis (Appendix 3 ) to create the final conservation design for the region (Fig. 5). This surface was used as a mask in the second MARXAN analysis to determine possible locations of mitigation solutions for the Caltrans projects in the study area.

Most of the needed habitat for a mitigation-potential portfolio is located in the grasslands-vernal pool complexes on the eastern edge of the study area (Fig. $6)$. One possible solution is illustrated with aerial photographs of several of the identified parcels (Fig. 6). This solution includes a rice field surrounded on three sides by canals. Such a location is currently used by waterfowl at certain times of the year and could potentially be managed for greater suitability for semi-aquatic species such as the giant garter snake. The eastern-edge parcels can be seen to be grasslands interspersed with vernal pools, a habitat type greatly reduced in California's Central Valley and harboring a number of species of management concern. The potential to combine mitigation with landscape connectivity is evident in Fig. 7, which shows how parcels from the same model run would partially help preserve a southern corridor in the region.

Finally, another ancillary use of the connectivity analysis-identification of intersections between proposed road construction and potential corridors -was identified by overlaying the portfolio with the road projects to identify where on-site mitigation actions might be able to contribute to landscape connectivity (Fig. 8).

\section{DISCUSSION}

These studies demonstrate the process of identifying regional conservation priorities and using them as a framework within which to seek mitigation solutions to agency obligations. In the United States, legal developments have put the basic concepts needed to promote this approach into guidelines through the passing of SAFETEA-LU (U.S. Congress 2005) and the "Eco-Logical" report (Brown 2006). The approach is based on systematic conservation-planning principles, transparent assumptions, and repeatable methods. This allows other stakeholders and agencies working in the same watershed to understand how the conservation and mitigation planning decisions were made. Such transparency may promote interest from other stakeholders and government agencies, leading to the possibility of multi-agency, broad stakeholder groups that can each contribute some piece to the conservation of regional ecological sustainability.

A number of lessons emerged from comparison of the two studies. First, a regional conservation assessment or greenprint is essential. A greenprint can be defined in various ways, some of which were demonstrated in this study, i.e., habitat representation and landscape connectivity. Ideally, a greenprint should address biodiversity hotspots or other unique ecological features, presence of threatened and endangered species, ecosystem processes such as fire and hydrology, and landscape connectivity.

Local stakeholders can assist greatly with the conservation and mitigation planning process. In the ES study, the ESF had a wealth of information about biological resources, as well as the capacity to manage lands purchased for mitigation. The lack of such capacity in the PG study meant we had to use our best estimates about conservation target levels and that options for management of lands acquired for mitigation were very limited because Caltrans is not permitted to manage lands itself, but must transfer acquired mitigation parcels to a third party.

This condition may be similar to that of other transportation agencies. In California, traditional land-management partners such as the California State Parks Department or the U.S. Fish and Wildlife Service may not be willing to accept new management obligations if mitigation lands are not adjacent to existing reserves. However, transportation agency mitigation obligations may require acquisition of such parcels. Therefore, it may be in the interest of transportation agencies to foster landmanagement capacity in non-governmental groups so they can be partners for implementation of regional mitigation goals. This rather counterintuitive result means a new type of relationship is possible 
Fig. 4. The Elkhorn Slough regional greenprint and mitigation portfolios, as identified through the MARXAN runs. The upper image is the regional conservation potfolio using representation targets set by the local environmental group, the Elkhorn Slough Foundation. The lower image is a portfolio of sites that could meet the mitigation needs for four Caltrans projects planned in the watershed. The darkest-blue parcels contain biological resources that are limited, and thus, are more difficult to substitute for other parcels. The lighter parcels may be just as highly suitable, but the resources they contain could be found on other parcels. In the lower map, any parcel with a color other than tan, can be thought of as a candidate for fulfilling mitigation obligations.
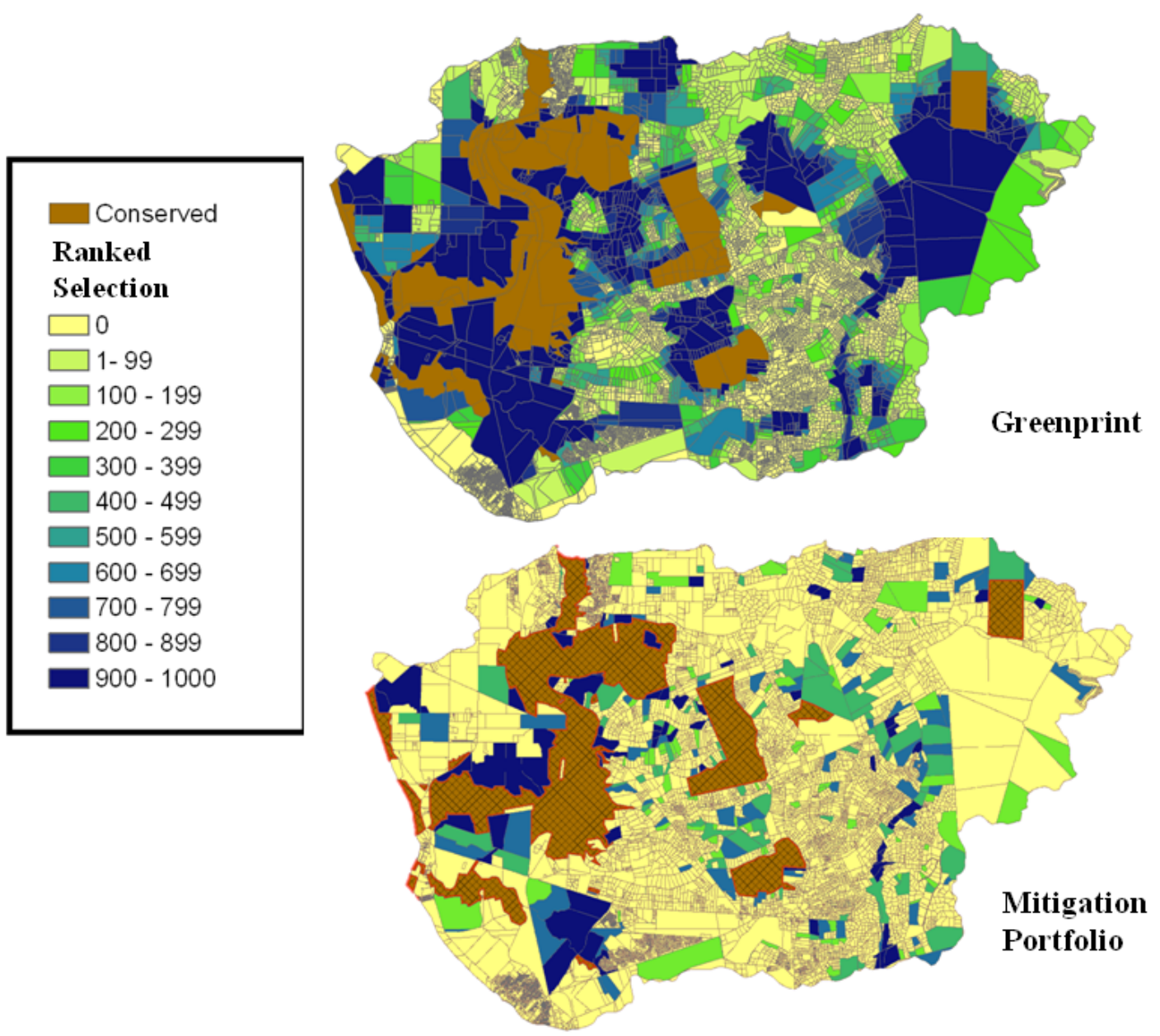

between infrastructure agencies and the conservation community.

The condition of the landscape is a necessary consideration; in many situations, pristine natural lands may not be available and mitigation planners will need to consider restoration ecology as part of the regional plan. We found habitat in both study areas required restoration, at different levels. In the ES watershed, the ESF has an active program to improve water quality to the estuary by restoration of riparian buffers and some steeply sloped farmlands. We did not specifically include restoration in our calculations for ES because we 
Fig. 5. Regional conservation greenprint based on combined habitat and "core" and connectivity values. Each parcel was assigned a score equal to the maximum of either the "core" or connectivity scores.

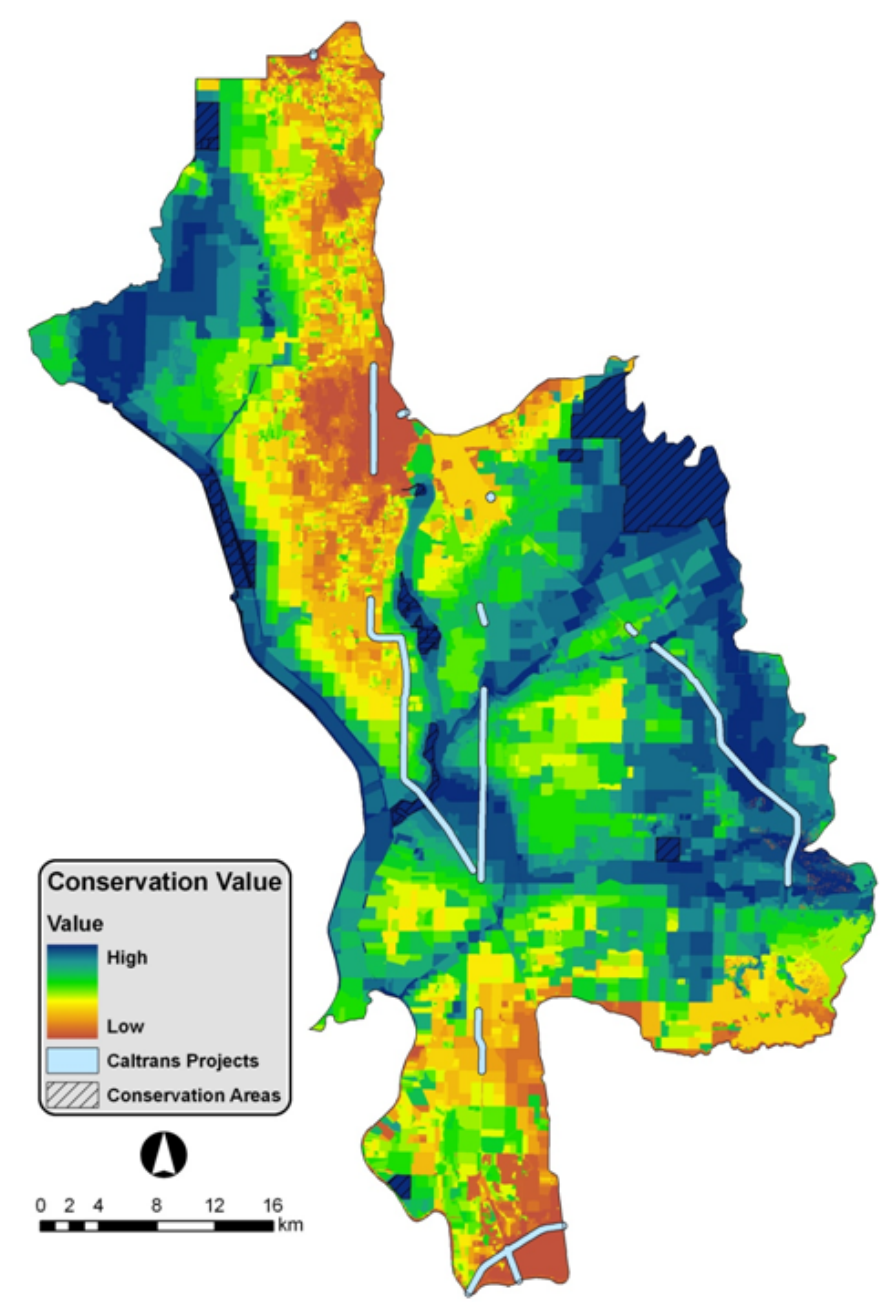

assumed the land manager would do this work at the site level once lands were acquired. However, we did in PG, where approximately $70 \%$ of the region is heavily converted. The inclusion of species-specific habitat models permitted us to consider agricultural parcels that would need restoration to make them suitable as long-term conservation lands.

Good-data quality (i.e., maps) about the location of biological resources are very important for successful regional mitigation assessment. The highest level of accuracy about extent and composition of habitat types will always come from field surveys. Given the long lead times for road projects, it may be possible to get field surveys for each of the projects that are bundled for regional assessment. This is the preferred alternative. We used the best available data in each case, but landcover maps will always be limited by what types they portray and the minimum resolution they can represent. The PG study in particular used a landcover map that has necessarily coarse land-cover classes because it spans the entire state. Species that are hard to detect, or that are little known, may have been missed in that study, so it is critical to interact with local experts, if they are available. 
Fig. 6. Results from the MARXAN scenario showing possible mitigation-needs solutions for the Pleasant Grove area. In this scenario, all public lands and lands within the levee system are considered to be conservation areas. The darker-brown parcels are those selected often by MARXAN as potentially meeting Caltrans mitigation needs. A sample "best" MARXAN solution (red parcels meet mitigation obligations with a low cost) is shown, with two aerial imagery insets (NAIP 1-m resolution, USDA 2005). The top inset shows a selected rice field parcel that could potentially serve as T. gigas habitat whereas the lower inset shows five adjacent selected parcels that combine to form a portion of a grassland corridor (running east-west). These grassland parcels also potentially harbor vernal pools.

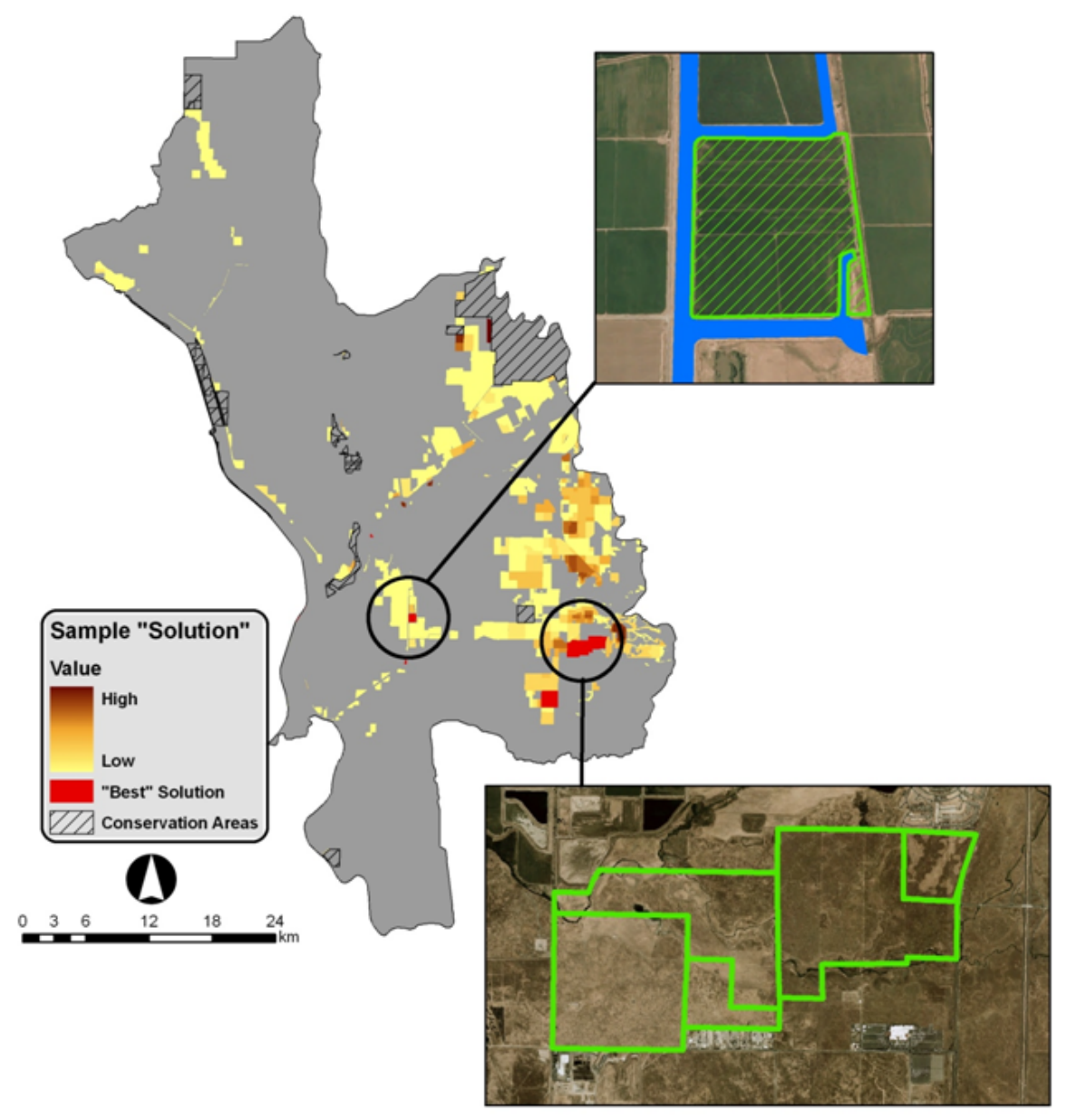

The project footprint approach is similar to the definition of "road-effect zone," which is the distance of ecological impact from a road (Forman and Deblinger 1999). However, the measure used here is an estimate of the direct impacts from the construction of the road. This distance is likely less than the overall impacts a road may have, but the direct impacts can be estimated and are what Caltrans is legally obligated to offset. Over the lifetime of a road, cumulative ecological impacts and a broader spatial impact may become evident, however, this study only addressed the estimated impacts from road construction. The Caltrans biologists are quite familiar with the degree to which 
Fig. 7. The same potential mitigation solution from MARXAN shown overlaying the connectivity modeling surface for the Pleasant Grove study area. Acquisition of this set of parcels could contribute to maintaining and restoring some landscape connectivity. With the exception of the square parcel in the southeast, all of these parcels lie on modeled least-cost corridors.

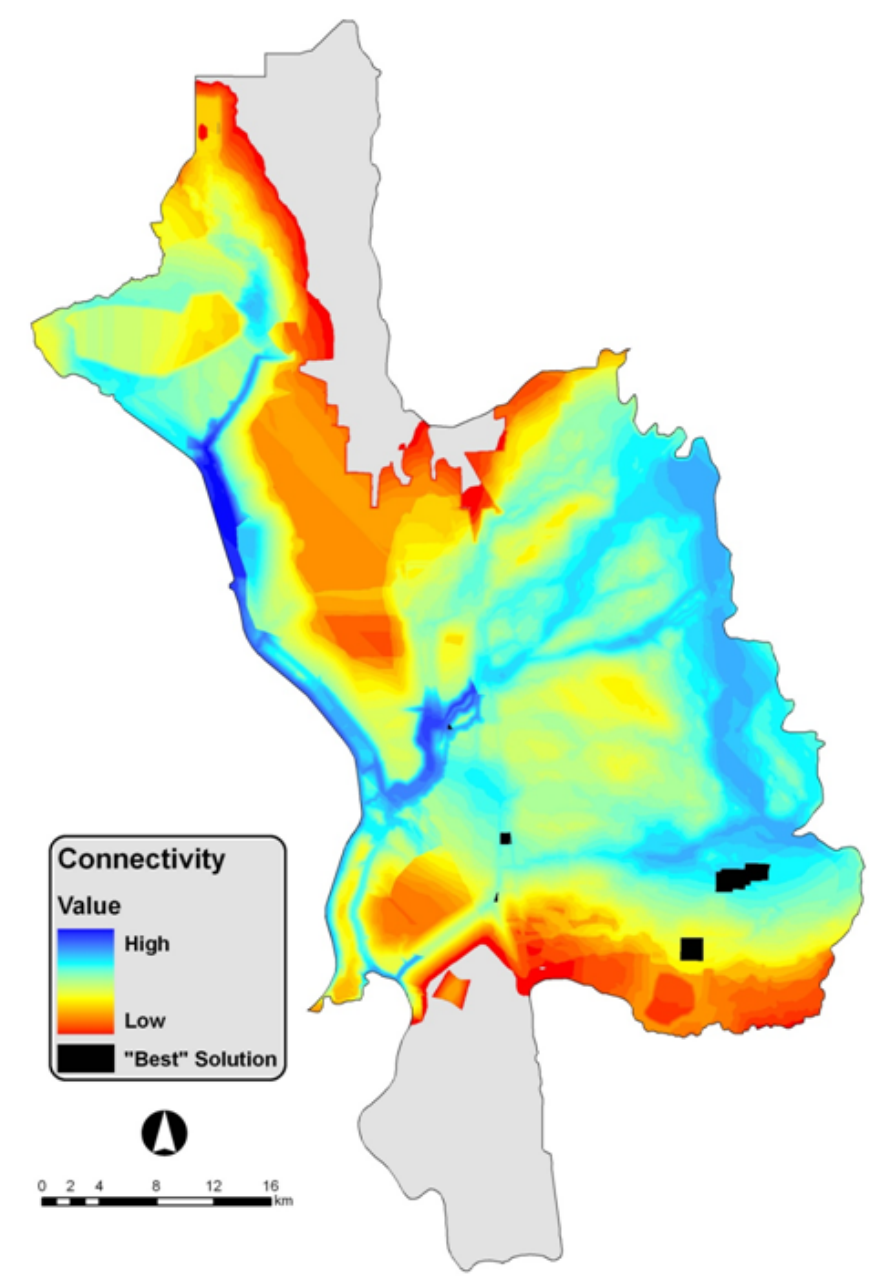

different types of construction will impact habitat (Appendix 2) and they also were able to identify what mitigation ratios were likely to be required because they had seen other similar projects assessed. In practice, these direct impacts of road construction tend to be the component required to be offset by regulatory agencies, and hence, the extent of transportation agency concern.

Land-value information about parcels was critical for financially sound decisions about prioritizing parcels for mitigation and for inclusion in the MARXAN analysis. Although many parcels may be suitable for mitigation, the per-area cost can vary widely. However, we found that the price of a parcel can be roughly estimated by its size, with larger parcels costing less per unit area. Due to this inverse relationship, it will often be more economical to purchase a single or a few larger parcel(s) that contain multiple biological resources, rather than purchasing many smaller parcels. Obtaining the best and most up-to-date information on parcel 
Fig. 8. Six locations of programmed road-construction projects that overlap modeled high connectivity areas. These identified locations could be considered for on-site mitigation measures (a regulatory preferable solution to potential environmental impact) designed to preserve or enhance regional connectivity. The photos reveal that these locations are frequently associated with bridges over riparian vegetation.

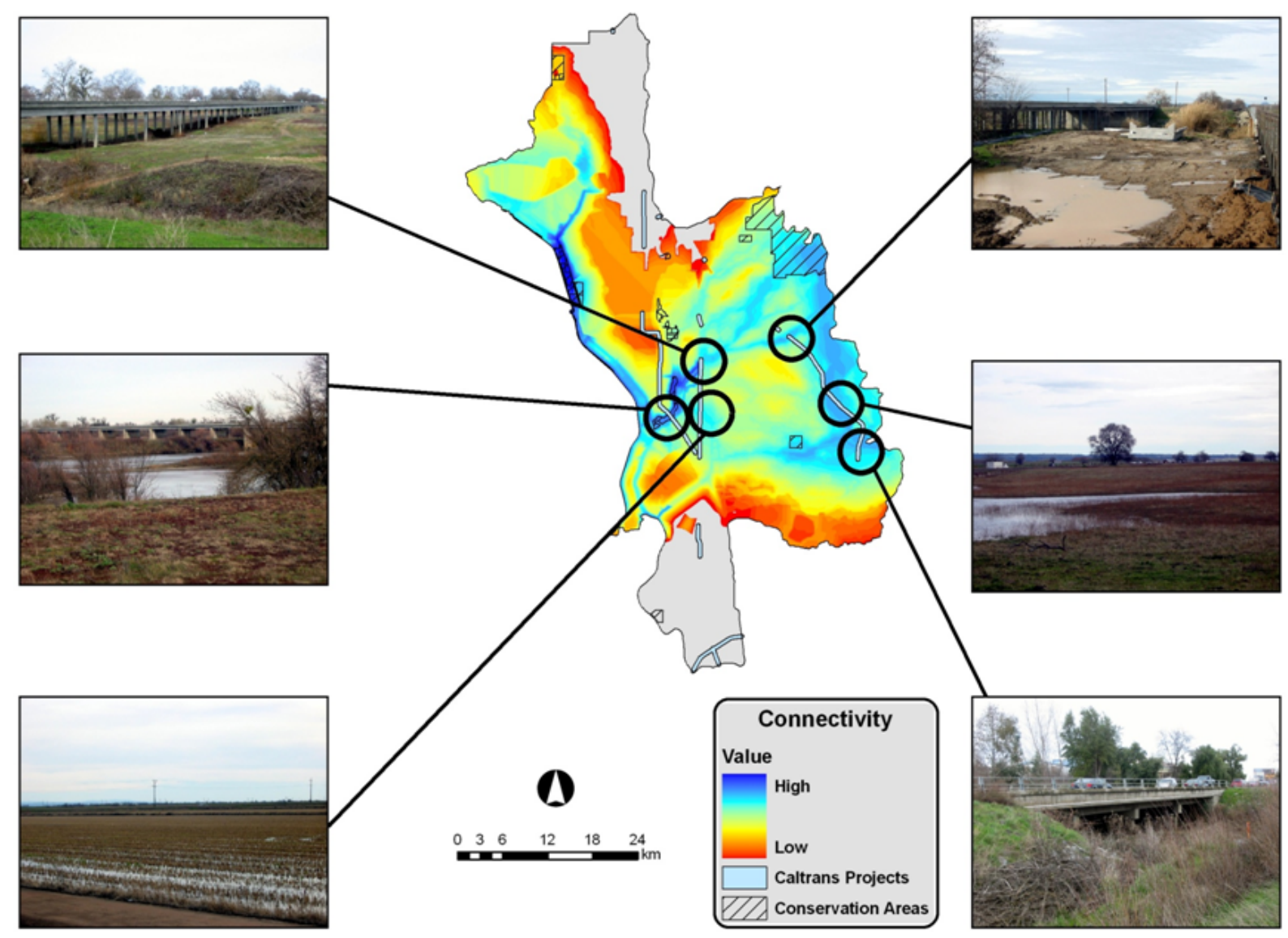

boundaries and parcel values, even if these have to be digitized from paper records, will assist with making systematic conservation and mitigation planning more financially economical.

Moreover, it can be more financially economical to purchase more land than immediately needed if a given large parcel contains many of the resources needed for mitigation. This approach can be used to create a mitigation bank, where environmental credits are available to be used as new projects define their impacts. For compensatory wetland mitigation in the U.S., this approach is required by the U.S. Army Corps of Engineers. The model may possibly be useful to groups attempting to set regional mitigation goals that include not only wetland habitat types but other habitat types as well.

One of the main benefits to transportation agencies for participating in regional planning is the potential 
for faster environmental review, which is the leading cause of expensive delays in California (Byrne 2005). For example, the PG study area contained 18 road-construction projects scheduled for construction between 2003 and 2012. The size of these projects ranged from 0.01 to 315.4 ha (Appendix 3). Between them, they impact nine habitat types (Appendix 4), which will need to be reviewed, and mitigation assigned and completed. This process will be time consuming. Using the regional planning approach, the major impacts can be proactively assessed, and mitigation responsibilities combined, which will save the agency time and money.

A multi-scale approach to mitigation planning, including wildlife corridors that extend beyond the study area, can ensure that mitigation acquisitions optimally add to a regional greenprint. The ES study identified watershed-scale conservation targets, but landscape connectivity was not included. However, a regional connectivity assessment indicates the need for a wildlife corridor running north-south in the eastern end of the watershed (Thorne et al. 2006a), requiring post hoc consideration of the connectivity utility of mitigation portfolio sites. The PG analysis explicitly included landscape connectivity, with a multi-species-based set of corridors both across and within the study area. Hydrological connectivity, not modeled, is also essential in both regions to support anadromous fish populations and other aquatic concerns.

Infrastructure agencies are not required to-and won' $t$ - meet all the conservation goals for a region through their mitigation obligations. But, regional greenprints can be used to better integrate regional mitigation, as shown here. The longevity of infrastructure agencies makes their partnerships with conservation planners a valuable asset. There is no implication that infrastructure agencies are responsible for conserving the regional ecological networks, but NGOs and conservation planners should consider the opportunities of partnering with these groups as society strives to achieve regional sustainability.

Responses to this article can be read online at: http://www.ecologyandsociety.org/voll4/iss 1/art47/ responses/

\section{Acknowledgments:}

This study was funded by the California Department of Transportation, Division of Environmental Analysis.

\section{LITERATURE CITED}

American Association of State and Highway Transportation Officials. 2003. Causes and extent of environmental delays in transportation projects. American Association of State and Highway Transportation Officials, Washington, D.C., USA.

Ball, I. R., and H. P. Possingham. 2000. MARXAN (V1.8.2): marine reserve design using spatially explicit annealing, a manual. University of Queensland, Brisbane, Australia. [online] URL: ht tp://www.uq.edu.au/marxan/index.html?page $=803 \overline{65}$

Beier, P., D. R. Majka, and W. D. Spencer. 2008. Forks in the road: choices in procedures for designing wildland linkages. Conservation Biology 22:836-851.

Beier, P., and R. F. Noss. 1998. Do habitat corridors provide connectivity? Conservation Biology 12: $1241-1252$.

Brown, J. W. 2006. Eco-logical: an ecosystem approach to developing infrastructure projects. Office of Project Development and Environmental Review, Federal Highway Administration, Washington, D.C., USA.

Byrne, M. 2005. Preliminary environmental analysis report tool. California Department of Transportation, Sacramento, California, USA.

California Department of Fish and Game (DFG). 2007. California natural diversity database $(C N D D B)$. Resources Agency, Sacramento, California, USA.

California Department of Forestry and Fire Protection (FRAP). 2002. Multi-source land cover data. California Department of Forestry and Fire Protection, Sacramento, California, USA. 
California Interagency Watershed Mapping Committee (CIWMC). 2004. California interagency watershed map of 1999 (CalWater 2.2.1). California Resources Agency, Sacramento, California, USA.

California Resources Agency. 2007. Public, conservation and trust lands, v05_2. California Resources Agency, Sacramento, California, USA.

California Spatial Information Library. 2000. Tiger 2000 Transportation Layer-Local Roads. California Resources Agency, Sacramento, California, USA.

Cameron, S. E., K. J. Williams, and D. K. Mitchell. 2008. Efficiency and concordance of alternative methods for minimizing opportunity costs in conservation planning. Conservation Biology 22:886-896.

Clevenger,A.P., B. Chruszczc, and K. E. Gunson. 2003. Spatial patterns and factors influencing small vertebrate fauna road-kill aggregations. Biological Conservation 109:15-26.

Dale, V., S. Archer, M. Chang, and D. Ojima. 2005. Ecological impacts and mitigation strategies for rural land management. Ecological Applications 15:1879-1892.

Davis, F. W., D. M. Stoms, A. D. Hollander, K. A. Thomas, P. A. Stine, D. Odion, M. I. Borchert, J. H. Thorne, M. V. Grey, R. E. Walker, K. Warner, and J. Graae. 1998. The California gap analysis project: final report. University of California, Santa Barbara, California, USA.

Elkhorn Slough Foundation (ESF) and T. Scharffenberger. 2002. Elkhorn Slough at the crossroads: natural resources and conservation strategies for the Elkhorn Slough watershed. Elkhorn Slough Foundation, Moss Landing, California, USA.

Elkhorn Slough Foundation (ESF) and The Nature Conservancy (TNC). 1999. Elkhorn Slough Watershed Conservation Plan. Elkhorn Slough Foundation, Moss Landing, California, USA.

Florida Department of Transportation. 2001. Environmental Management Office. [online] URL: fdotenvironmentalstreamlining.urs-tally.com/.
Forman, R.T.T.2000. Estimate of the area affected ecologically by the road system in the United States. Conservation Biology 14:31-35.

Forman, R. T. T., and L. E. Alexander. 1998. Roads and their major ecological effects. Annual Review of Ecology and Systematics 29:207-231.

Forman, R. T. T., and R. D. Deblinger. 1998. The ecological road-effect-zone on a Massachuetts (USA) suburban highway. Conservation Biology 14:36-46.

Forman, R. T. T., D. Sperling, J. A. Bissonette, A. P. Clevenger, C. D. Cutshall, V. H. Dale, L. Fahrig, R. France, C. R. Goldman, K. Heanue, J. A. Jones, F. J. Swanson, T. Turrentine, and T. C. Winter. 2003. Road ecology: science and solutions. Island Press, Washington, D.C., USA.

Girvetz, E. H., J. H. Thorne, J. A. Jaeger, and A. M. Berry. 2008a. Integration of landscape fragmentation analysis into regional planning: a statewide multi-scale case study from California, USA. Landscape and Urban Planning 86:205-218.

Girvetz, E. H., J. H. Thorne, J. F. Quinn, and M. C. McCoy. 2008b. Early biological mitigation needs assessment Elkhorn Slough pilot project: final report. Information Center for the Environment, University of California Davis, Davis, California, USA.

Hardy, A. 2007. Developing the integrated transportation and ecological enhancements for Montana process: applying the "Eco-logical" approach. Transportation Research Record 2011:148 156.

Hoctor, T., M. H. Carr, and P. D. Zwick. 2000. Identifying a linked reserve system using a regional landscape approach: the Florida ecological network. Conservation Biology 14:984-1000.

Huber, P. R. 2008. The effects of spatial and temporal scale on conservation planning and ecological networks in the Central Valley, California. Dissertation, University of California, Davis, California, USA.

Huber, P. R., E. H. Girvetz, J. H. Thorne, A. Hollander, J. F. Quinn, and M. C. McCoy. 2008. Early biological mitigation needs assessment 
Pleasant Grove pilot project: final report. Information Center for the Environment, University of California Davis, Davis, California, USA.

Jaeger, J. A. G. 2000. Landscape division, splitting index, and effective mesh size: new measures of landscape fragmentation. Landscape Ecology 15:115-130.

Lambeck, R. J. 1997. Focal species: a multispecies umbrella for nature conservation. Conservation Biology, 11:849-856

Margules, C. R., and R. L. Pressey. 2000. Systematic conservation planning. Nature 405:243253.

Miller, H. J. 1999. Potential contributions of spatial analysis to geographic information systems for transportation (GIS-T). Geographical Analysis 31:373-399.

National Academy of Sciences. 2005 Assessing and managing the ecological impacts of paved roads. National Academies Press, Washington, D. C., USA.

O'Neill, R. V., C. T. Hunsaker, K. B. Jones, K. H. Riitters, J. D. Wickham, P. M. Schwartz, I. A. Goodman, B. L. Jackson, and W. S. Baillargeon. 1997. Monitoring environmental quality at the landscape scale: using landscape indicators to assess biotic diversity, watershed integrity, and landscape stability. BioScience 47:513-519.

Orlowski, G. 2008. Roadside hedgerows and trees as factors increasing road mortality of birds: implications for management of roadside vegetation in rural landscapes. Landscape and Urban Planning 86:153-161.

Scott, J. M., F. Davis, B. Csuti, R. Noss, B. Butterfield, C. Groves, H. Anderson, S. Caicco, F. Derchia, T. C. Edwards, J. Ulliman, and R. G. Wright. 1993. Gap analysis-a geographic approach to protection of biological diversity. Wildlife Monographs 123:1-41.

Smith-Patten, B. D., and M. A. Patten. 2008. Diversity, seasonality, and context of mammalian roadkills in the southern great plains. Environmental Management 41:844-852.

Svancara, L. K., R. Brannon, J. M. Scott, C. R.
Groves, R. F. Noss, and R. L. Pressey. 2005. Policy-driven versus evidence-based conservation: a review of political targets and biological needs. BioScience 55:989-995.

Thorne, J. H., D. Cameron, and J. F. Quinn. 2006a. A conservation design for the Central Coast of California and the evaluation of mountain lion as an umbrella species. Natural Areas Journal 26:137148.

Thorne, J. H., S. Gao, A. D. Hollander, J. A. Kennedy, M. McCoy, R. A. Johnston, and J. F. Quinn. 2006b. Modeling potential species richness and urban buildout to identify mitigation sites along a California highway. Journal of Transportation Research D 11:233-314.

Thorne, J. H., E. H. Girvetz, and M. C. McCoy. 2009. A multi-scale and context sensitive state-wide environmental mitigation planning tool for transportation projects in California. Environmental Management 43(5):936-948. DOI 10.1007/ s00267-008-9246-8

Treweek, J., and N. Veitch. 1996. The potential application of GIS and remotely sensed data to the ecological assessment of proposed new road schemes. Global Ecology and Biogeography Letters 5:249-257.

Trombulak, S. C., and C.A. Frissell. 2000. Review of the ecological effects of roads on terrestrial and aquatic communities. Conservation Biology 14:1830 .

U.S. Congress. 2005. Safe, accountable, flexible, efficient transportation equity act (SAFETEA-LU). Washington, D.C., USA.

USDA. 2005. NAIP 1-meter resolution imagery. USDA-FSA-APFO NAIP County Mosaic. Washington, D.C., USA. 
APPENDIX 1. Overview of steps for setting up and running MARXAN

1. Select an appropriate study area boundary: Keep in mind that your choice here can have a dramatic impact on your ultimate MARXAN results. Inclusion of an area with certain biological resources will draw focus away from other areas containing those same resources.

2. Create planning units GIS layer: These can be ownership parcels, uniform polygons (e.g. hexagonal grid), or other appropriate spatial units. Because MARXAN calculates the boundaries of conservation reserves, it is critical that the planning unit dataset used has clean boundaries between the units (e.g. no sliver polygons). A common problem with using parcel datasets is that they include roads as having a width in the map, which prevents adjoining parcels from being considered contiguous. To avoid this problem we removed the roads and extended parcel boundary lines to the centerlines of the roads to allow parcels to be considered adjacent to each other that would not otherwise be considered adjacent because a road right of way was between them.

3. Attribute planning units GIS layer and create planning unit MARXAN file: Each planning unit requires at a minimum three attributes: unique identification number, cost, and conservation status (already conserved, available to be conserved, or excluded from analysis). The cost can be either a true monetary cost of the unit or a proxy, such as the area of the unit. (See how the monetary cost was estimated for each parcel based on parcel size in the main text) Create a planning unit text file using either manually in Excel (for further information see MARXAN user's manual section 3.2) or using automated tools designed for creating MARXAN input files (e.g. PANDA http://www.mappamondogis. it/panda en.htm or CLUZ http://www.mosaic-conservation.org/cluz/).

4. Select conservation targets and create conservation feature target file: These targets could be vegetation types, species occurrences, species' habitat, etc. In the Elkhorn Slough project, vegetation land cover types were the targets, while in the Pleasant Grove project habitat for selected focal species was additionally used. It is then necessary to create a conservation feature target text file manually using Excel that identifies the amount of each conservation target that is to be included in the final reserve selection.

5. Create a planning unit versus conservation feature text file: This can be accomplished manually by determining the amount of each of the conservation targets falling within the boundaries of each planning unit using a variety of GIS overlay techniques (e.g. zonal statistics or intersect), then converting this information into a text file format (for further information see MARXAN user's manual section 3.6). Alternatively, this can be accomplished using automated tools designed for creating MARXAN input files (e.g. PANDA or CLUZ).

6. Create a boundary length text file. The automated tools designed for creating MARXAN input files (e.g. PANDA or CLUZ) should be used to create the boundary length text file.

7. Create a MARXAN input parameter file. This includes information about where the input files are located, where the output files from the analysis should be placed, as well as a variety of parameters that tell MARXAN how to run the analysis. These parameters include the boundary modifier, the number of runs, number of iterations, and the type of optimization algorithm that should be used. In general, the default parameters are good to use unless otherwise noted. However, the boundary length modifier needs to be analyzed for a range of values, which are used to identify which single value from the range boundary modifiers is appropriate to use The type of optimization algorithm used for these analyses was simulated annealing, which seems to offer the best balance between analysis power and computing efficiency. The MARXAN input file can be created using the user-friendly inedit.exe program included with the MARXAN tool. The input parameter file created using this program should be called input.dat. Alternatively, the input parameters can be set using the automated tools designed for creating MARXAN input files (e.g. PANDA or CLUZ). 
8. Run MARXAN model. All of the input files should be located in a single directory (identified as the input directory in the input.dat file) along with the marxan.exe program. To run the model simply double click the marxan.exe program and if all of the input files are set up correctly, a box will appear and output messages about the model runs. Alternatively, the MARXAN model can be run using the automated tools designed for creating MARXAN input files (e.g. PANDA or CLUZ).

9. Output files: summed runs, best run, summary statistics

10. Displaying results and interpretation of output files: Using the summed runs gives you the best estimation of how important any given parcel is for meeting the conservation targets set for the analysis. For more information on the use of MARXAN, see methods manual (Ball and Possingham 2000) and literature at the MARXAN website: http://www.uq.edu.au/marxan/. 
APPENDIX 2. Classification of the distance out from road center line that different types of road projects are projected to impact.

The values presented here are the distance from road center line that different types of road construction projects will impact for California State highways. The distances were developed by Caltrans biologists and planners. A project footprint as described in the text would use this distance to buffer each side of the road, for the length of the project. This footprint can then be used to sample biological resource layers such as land cover maps, species locality maps, etc.

\section{Project Type}

New alignment

Reconstruct interchange and access ramps

Construct expressway

Construct new bridge

Widen roadway

Remove rail trestle

Realign curve

Grade separation improvements

Construct expressway existing alignment

Slow vehicles lane

Passing lanes

Construct lane

High occupancy lanes

Stabilize slope

Rehabilitate roadway

Construct noise barrier

Construct left turn lane

Construct retaining wall

Install median barrier

Roadside rest areas

Install warning devices

Install message signs/traffic operation systems

Install ramp metering
Footprint Width (Meters)

152.4

61.0

61.0

45.7

30.5

30.5

30.5

30.5

30.5

15.2

15.2

15.2

12.2

9.1

9.1

9.1

9.1

6.1

6.1

3.0

1.5

1.5

1.5 
APPENDIX 3. The inputs for the Pleasant Grove regional greenprint design consist of the MARXAN modeling to account for habitat and focal species (left) and modeled landscape connectivity (right). The darkest blue parcels contain the highest value biological resources because they are limited, and thus, are more irreplaceable. The greater value per parcel found by overlaying these two maps was the value that went into the final regional greenprint (Fig. 5, in the paper).
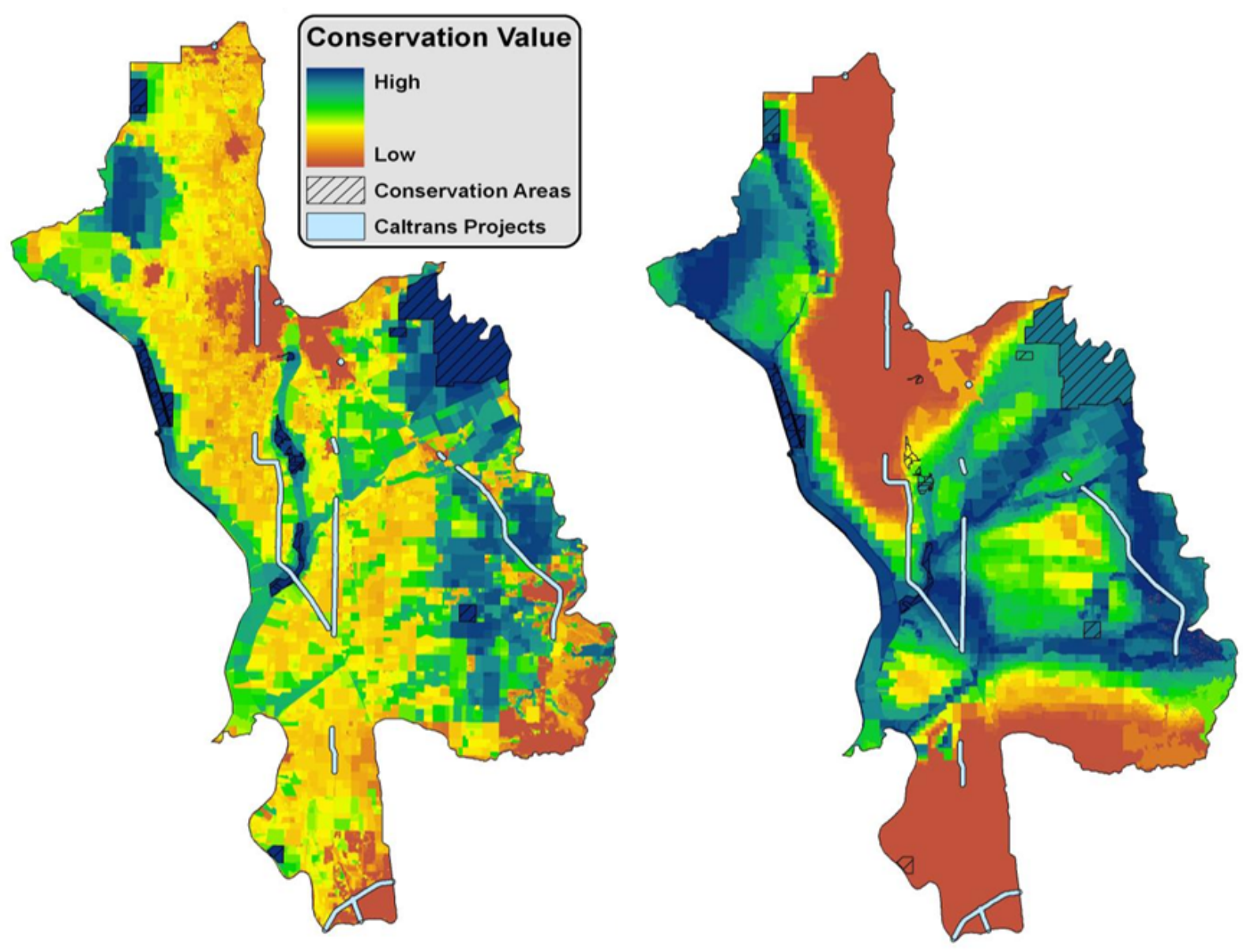
APPENDIX 4. The area of habitat expected to be impacted for each of the 18 projects in the Pleasant Grove study area.

This table shows the sometimes minute habitat areas that will be impacted by the programmed road construction in the Pleasant Grove study area. If the environmental review and mitigation obligation assessment, and the subsequent purchase of land for all these projects is done on a project-by-project basis, the whole process will take a considerable time, and each project's environmental review will typically start near the end of that project's lifecycle. Incorporation of regional planning offers the possibility of speeding the process through early assessment of projected habitat impacts and identification of associated mitigation needs; earlier acquisition of lands to fulfill mitigation obligations, which may be less expensive; and selection of mitigation sites that fit within a regional greenprint design.

\begin{tabular}{|c|c|c|c|c|c|c|c|c|c|c|c|c|}
\hline $\begin{array}{l}\text { ID } \\
\text { Code }\end{array}$ & $\begin{array}{l}\text { Project } \\
\text { type }\end{array}$ & Date & $\begin{array}{c}\text { Proj- } \\
\text { ect } \\
\text { Impact } \\
\text { ha }\end{array}$ & $\begin{array}{c}\text { Annual } \\
\text { Grassland } \\
\text { ha }\end{array}$ & $\begin{array}{c}\text { Blue } \\
\text { Oak } \\
\text { Pine } \\
\text { ha }\end{array}$ & $\begin{array}{c}\text { Blue } \\
\text { Oak } \\
\text { Woodland } \\
\text { ha }\end{array}$ & $\begin{array}{c}\text { Freshwater } \\
\text { Emergent } \\
\text { Wetland } \\
\text { ha }\end{array}$ & $\begin{array}{c}\text { Montane } \\
\text { Hardwood } \\
\text { ha }\end{array}$ & $\begin{array}{c}\text { Valley } \\
\text { Oak } \\
\text { Woodland } \\
\text { ha }\end{array}$ & $\begin{array}{c}\text { Valley } \\
\text { Riparian } \\
\text { ha }\end{array}$ & $\begin{array}{c}\text { Montane } \\
\text { Hardwood } \\
\text { Conifer } \\
\text { ha }\end{array}$ & $\begin{array}{c}\text { Rice } \\
\text { Fields } \\
\text { ha }\end{array}$ \\
\hline $\begin{array}{l}1 \mathrm{~A} 43- \\
10\end{array}$ & Add lane & 2003 & 7.30 & 0.14 & & & 0.12 & & & & & 1.45 \\
\hline 0A910 & $\begin{array}{l}\text { Widen } \\
\text { roadway }\end{array}$ & 2005 & 7.09 & 0.71 & & & 0.03 & & & 0.05 & & \\
\hline $\begin{array}{l}\text { 0A91- } \\
\text { 0K }\end{array}$ & $\begin{array}{l}\text { Install } \\
\text { TOS } \\
\text { elements }\end{array}$ & 2005 & 0.00 & & & & & & & & & \\
\hline $\begin{array}{l}\text { 1A16- } \\
0 \mathrm{~K}\end{array}$ & $\begin{array}{l}\text { Roadside } \\
\text { planting }\end{array}$ & 2005 & 2.17 & & & & & & & & & \\
\hline 2005 & $\begin{array}{l}\text { Upgrade } \\
\text { bridge rail }\end{array}$ & 2005 & 0.26 & & & & & & & & & \\
\hline $2 \mathrm{~A} 830$ & $\begin{array}{l}\text { Install } \\
\text { TOS } \\
\text { elements }\end{array}$ & 2005 & 0.00 & & & & & & & & & \\
\hline $\begin{array}{l}2 \mathrm{~A} 83- \\
0 \mathrm{~K}\end{array}$ & $\begin{array}{l}\text { Install } \\
\text { TOS } \\
\text { elements }\end{array}$ & 2005 & 0.00 & & & & & & & & & \\
\hline $\begin{array}{l}\text { no } \\
\text { code }\end{array}$ & $\begin{array}{l}\text { Signaliza- } \\
\text { tion }\end{array}$ & 2006 & 0.59 & 0.08 & & & & & & & & \\
\hline
\end{tabular}




\begin{tabular}{|c|c|c|c|c|c|c|c|c|c|c|c|c|}
\hline $\begin{array}{l}\text { 0A13- } \\
1 \mathrm{~K}\end{array}$ & $\begin{array}{l}\text { Upgrade } \\
\text { bridge rail }\end{array}$ & 2006 & 0.01 & & & & & & & & & \\
\hline $\begin{array}{l}\text { 1A91- } \\
\text { 0K }\end{array}$ & $\begin{array}{l}\text { Rehabilitate } \\
\text { roadway }\end{array}$ & 2007 & 3.92 & 0.01 & & & & & & 0.01 & & \\
\hline 386410 & $\begin{array}{l}\text { Construct } \\
\text { expressway }\end{array}$ & 2007 & 52.45 & 3.16 & & & 0.17 & & & & & 33.72 \\
\hline 386420 & $\begin{array}{l}\text { Construct } \\
\text { expressway }\end{array}$ & 2007 & 32.50 & 2.64 & & & 0.83 & & 0.05 & 0.85 & & 10.07 \\
\hline $\begin{array}{l}3 \mathrm{~A} 27- \\
0 \mathrm{~K}\end{array}$ & Add lane & 2007 & 0.36 & 0.01 & & & & & & & & \\
\hline $\begin{array}{l}2 \mathrm{~A} 27- \\
20\end{array}$ & $\begin{array}{l}\text { Construct } \\
\text { interchange }\end{array}$ & 2008 & 7.66 & 2.23 & & & 0.19 & & & & & 5.17 \\
\hline 1A461 & Add lane & 2009 & 14.02 & 0.08 & & & & & & & & 0.77 \\
\hline 333800 & $\begin{array}{l}\text { New } \\
\text { alignment }\end{array}$ & 2009 & 315.42 & 133.31 & 1.81 & 8.08 & 3.92 & 6.32 & & 2.31 & 0.45 & 4.28 \\
\hline 40660 & $\begin{array}{l}\text { Construct } \\
\text { interchange }\end{array}$ & 2009 & 25.72 & & & & & & & & & 25.72 \\
\hline 297300 & $\begin{array}{l}\text { Construct } \\
\text { expressway }\end{array}$ & 2012 & 2.37 & & & & & & & & & 0.51 \\
\hline
\end{tabular}

